\title{
АНАЛІЗ ФАКТОРІВ ТА МОДЕЛЕЙ ПОВЕДІНКИ СПОЖИВАЧА
}

\author{
Жалдак Г. П., канд. екон. наук, доцент \\ Яценко А. М., студентка \\ Національний технічний університет України «Київський \\ політехнічний інститут імені Ігоря Сікорського»
}

Постановка проблеми. Важливою передумовою успіху компанії є вдале проведення досліджень щодо реакції споживачів на продукцію підприємства i подальший аналіз прийнятих ними рішень під впливом цієї реакції. Далі 3 урахуванням таких досліджень будується маркетингова стратегія підприємства, спрямована на найповніше задоволення споживчих потреб і запитів кінцевих споживачів. Поряд із цим, актуальним заданням забезпечення функціонування компанії $є$ вміння вчасно передбачити зміни в перевагах споживачів, щоб у потрібний момент внести корективи у складові процесів виробництва продукції та комплексу маркетингу, і тим самим забезпечити низку вагомих переваг компаній у конкурентному середовищі в майбутньому.

Раніше компанії приділяли більше уваги дослідженням нових технологій виробництва, адже наявність більшої кількості характеристик товару прямопропорційно визначала кількість покупців. Більш конкурентоспроможною була та компанія, рівень інновацій якої був вищий. Зараз ситуація змінилася. З'явилася величезна кількість подібних товарів, причому на будь-який смак та за доступною ціною. Як же в таких умовах підприємство може виокремитися 3-поміж своїх конкурентів? Можна піти одним шляхом і проводити постійну реінновацію продуктів. Проте варто зазначити, що це доволі ресурсозатратний метод і не завжди дієвий, оскільки немає гарантії, що споживачі позитивно сприйматимуть ті чи інші зміни в товарі. Крім того чим більше нових характеристик матиме продукт, тим дорожчим він буде. Якщо це не товар першої необхідності, який не має товарівзамінників, то скоріш за все покупці обиратимуть більш дешевий варіант інших компаній.

Щоб не витрачати захмарні суми грошей на розробку нових технологій виробництва, можна обрати інший шлях і більш детально приділити увагу дослідженням поведінки споживачів. У результаті успішними $є$ ті компанії, які провела достовірний аналіз поведінки споживача у процесі купівлі.

Аналіз останніх наукових досліджень і публікацій. Спроби дослідити поведінку споживачів та визначити основні фактори впливу на ії формування зроблені в працях таких вчених як Д. Енджел, Р. Беркуелл, П. Мініард, Ф. Котлер, Р. Армстронг. Серед вітчизняних авторів свій внесок у вивченні моделей поведінки споживача зробили Н. Богомаз, О. Вачевський, А. Дечко, О. Зозульов, Р. Іванова, С. Скибінський, О. Шафалюк та інші. 
Невирішені складові загальної проблеми. На основі аналізу досліджень авторами визначено необхідність провести аналітичне дослідження стосовно змін споживача про купівлю товарів в залежності від зміни зовнішніх та внутрішніх факторів; визначити особливості поведінки покупців враховуючи споживчі переваги продукту та структуру споживання.

Формулювання цілей статті. Мета статті - окреслити основні фактори та моделі поведінки споживача в сучасних умовах.

Виклад основного матеріалу дослідження. На думку сучасних соціологів-економістів в господарській системі постіндустріального суспільства акценти поступово зміщуються 3 процесів виробництва на процеси споживання. Неухильне зростання споживання $\epsilon$ необхідною умовою суспільного процвітання. Отже, процес споживання стає основним ритуалом сучасного суспільства $[1$, С. 143$]$.

Споживач прагнучі задовольнити свої потреби та максимізувати корисність від споживання виконує функцію суб'єкта ринку. Тобто, зрозуміло, що виробники орієнтовані на бажання та потреби споживачів, адже немає ніякого сенсу виробляти те, що не буде купуватися. Таким чином споживач бажаючи задовольнити свої потреби, формує попит на певний набір товарів та впливає на обсяг цього попиту.

Вчені виділяють декілька основних припущень щодо аналізу поведінки споживачів:

- аналіз уподобання стосується певного моменту. 3 часом уподобання окремого індивідуума змінюються;

- уподобання не залежать від обсягу доходу та ціни, тоді як вибір залежить від уподобань та обмежень, зумовлених ціною товарів та доходом;

- незважаючи на те, що всі уподобання суб'єктивні, вони впливають на всі види людської діяльності [2, С. 152].

Проте варто зазначити, що навіть маючи однаковий дохід, споживачі можуть мати різні вподобання і відповідно при цьому приймати різні рішення щодо покупки того чи іншого товару. Відповідно до цього було б неправильно спираючись на результати досліджень, будувати стратегію підприємства, яка буде однаковою абсолютно для всіх споживачів. У цьому і заключається основна складність досліджень мікроекономічної теорії, що неможливо дослідити і передбачити споживацьку поведінку абсолютно всіх суб'єктів ринку. Тому підприємства вимушені обирати такі стратегії продажу, які будуть задовольняти якщо не всіх, то хоча б більшу частину населення.

В умовах появи все більшої кількості підприємств, а відповідно і більшої кількості товарів, головним джерелом конкуренції стає надлишок продукту. Серед величезної кількості товарів споживачам важко визначити, що саме їм потрібно, відповідно вони шукають у товарах ті характеристики, за якими їх можна диференціювати.

У статті «Труднощі вибору» рекламістка Глорі Карлберг пояснила це явище так: «Багато років тому теоретики мерчандайзингу визначили, що в разі наявності вибору потенційному покупцеві складніше відмовитись. Однак, 
можливо, нинішній надлишок вибору збиває покупців з пантелику, і ті радше будуть вдовольнятися старою моделлю, щоб не обирати між 23 розрекламованими варіантами» [3, С. 20].

Саме тому зараз успіх підприємства вирішує не лише унікальна технологія виробництва, а й вдалий аналіз споживчої поведінки та змога передбачити, як поведе себе покупець в тих чи інших умовах.

Спеціалісти виділяють 2 типи поведінки споживачів: позитивну та негативну. Позитивна - це така поведінка, коли споживач здійснює купівлю продукту. Негативна - полягає у стриманні покупця від придбання товару. Така поведінка є прихованою від продавця, адже той не може передбачити наперед, що споживач не має наміру купувати продукт. Негативна поведінка у свою чергу набуває 2 станів: стриманість та терпіння. Споживач стримує себе, коли на його поведінку впливають зовнішні фактори. Проте при цьому у нього $\epsilon$ бажання і змога задовольнити свою потребу. Наприклад, він шукає більш якісний продукт, тому відмовляється купувати там, де якість товарів низька. Поведінка терпіння являє собою відмову від покупки товару через брак можливостей для придбання. Тобто у споживача $є$ потреба придбати те чи інше благо, але з певних причин не вистачає ресурсів для задоволення цієї потреби.

Поведінка споживачів визначається мотиваційною та ситуаційною складовими. Мотиваційна складова формує напрямок поведінки покупця, а ситуаційна у свою чергу вказує ситуаційний вплив в рамках сформованого напрямку. Поряд із цим, домінуючими мотиваційними теоріями, які використовують для аналізу поведінки споживачів є:

1. Теорія Фрейда. Відповідно до цієї теорії, людина не усвідомлює до кінця причини здійснюваних нею вчинків. Вони знаходяться глибоко в нашій підсвідомості. Наприклад, жінки ретельно відносяться до випічки, так як цей процес підсвідомо асоціюється у них 3 процесом пологів. А куріння замінює смоктання пальця в дитинстві.

2. Теорія Маслоу. А. Маслоу виділив ряд потреб людини і проранжував їх. Згідно з А. Маслоу, потреби більш високого рівня не будуть задовольнятися до тих пір, поки не будуть задоволені потреби нижчого рівня. Потреби по А. Маслоу можуть бути представлені у формі піраміди [4, С. 92].

Прийнято вважати, що споживачам притаманна раціональна поведінка під час акту купівлі. Автори погоджуються з цим твердженням, оскільки кожен прагне до того, аби максимізувати загальну користь від споживання певних благ, орієнтуючись при цьому на наявні бюджетні обмеження. Як правило, раціональні споживачі звертають увагу на якість, ціну товару. Порівнюючи та аналізуючи ці данні споживач робить свій вибір.

Раціональними моделями споживацької поведінки можна визнати ті, які: не виходять за межі реального доходу; сприяють створенню оптимального балансу витрат і надходжень відповідно до структури споживання, що склалася й раціонально дозувалася; забезпечують контроль і нормування структури споживання і відповідних їм витрат, що не перевищують ліміти реального 
доходу; сприяють резервуванню частини засобів з метою страхування від непередбачених ситуацій та обставин [5, С. 180-181].

Та чи завжди поведінка споживача керується функціональними факторами попиту і чи завжди в такому випадку поведінку споживача можна вважати раціональною? Як показує практика, покупці піддаються впливу різних психологічних факторів, що у свою чергу зумовлює «неекономічну» поведінку споживача. Так, наприклад, окрім ціни та якості продукту, на вибір людини також впливають іï настрій, емоційний стан, темперамент.

Враховують також особисті відмінності споживачів. Вплив індивідуальних особистісних якостей на споживацьку поведінку розглянуто О. Дейнекою [5, С. 185] (табл. 1).

Таблиия 1

Взаємозв'язок особистісних якостей і споживацької поведінки

\begin{tabular}{|c|c|}
\hline Особові якості & Особливості процесу покупки \\
\hline Більш цілеспрямовані & $\begin{array}{c}\text { Більш обережні в економічній поведінці, менше уваги } \\
\text { приділяють другорядним ознакам товару і більш } \\
\text { змістовним }\end{array}$ \\
\hline Більш настирні & $\begin{array}{c}\text { Виражена пошукова активність у поведінці споживача, } \\
\text { послідовність і уникнення впливу ситуативних } \\
\text { авторитетів. }\end{array}$ \\
\hline Рішучість і самовладання & $\begin{array}{c}\text { Пов’язані з ризиком, прагненням до новизни, 3 } \\
\text { відсутністю боязні купувати нові товари. }\end{array}$ \\
\hline Високий рівень емпатії & $\begin{array}{c}\text { Більше турбуються з приводу правильності вибору } \\
\text { товару. Раціональна ж оцінка товару часто } \\
\text { відбувається вже після здійснення ним покупки. }\end{array}$ \\
\hline $\begin{array}{c}\text { Яскраво виражена афіліативна } \\
\text { потреба }\end{array}$ & $\begin{array}{c}\text { Більшою мірою при виборі товару спираються на } \\
\text { інформацію, одержану з реклами. }\end{array}$ \\
\hline Чутливість до зневаги іншими & Переживають почуття провини, проявляють \\
ретельність, завзятість і недовіру. Чим довше та \\
уважніше така людина вивчає товар, тим сильніше в \\
неї негативні емоції, пов'язані зі страхом, що про неї \\
погано подумають.
\end{tabular}

Джерело: [5, С. 185]

Окрім емоційних факторів на поведінку споживача впливає також соціальний фактор, коли індивід приймає рішення, відштовхуючись від поведінки свого оточення. У такому випадку попит на товар залежить не від якості та ціни на продукцію, а від моди, престижу, бажання споживача справити враження на інших.

У свою чергу, модель поведінки споживача визначається як формалізований опис зв'язку між діями людини та мотивами, що обумовлюють ці дії, а також чинниками, що визначають особисті характеристики споживача та особливості розвитку зовнішнього економічного середовища [6, С. 2].

Для визначення основних ефектів споживацької поведінки було проведено дослідження. Для цього було обрано товари, якими користується переважна кількість населення, а саме товари побутової техніки. Для збору 
даних був застосований метод опитування за допомогою анкетування 3 використанням Google Формы. Проаналізовано відповіді 85 респондентів, 58\% 3 яких жінки, а $42 \%$ - чоловіки. За соціальним становищем $92 \%$ опитуваних це студенти, а інші $8 \%$ працююча частина населення. Всі респонденти відносяться до різних вікових категорій, проте переважна кількість опитуваних віком від 18 до 30. 3 тих 8\% працюючих шоста частина займає посаду менеджера нижчого рівня, економіста або маркетолога з доходом понад 10 тис. грн.; 8.3\% працюють у сфері IT-послуг або у сфері консалтингу та мають дохід понад 25 тис. грн. Решта опитуваних не працюють або ж студенти.

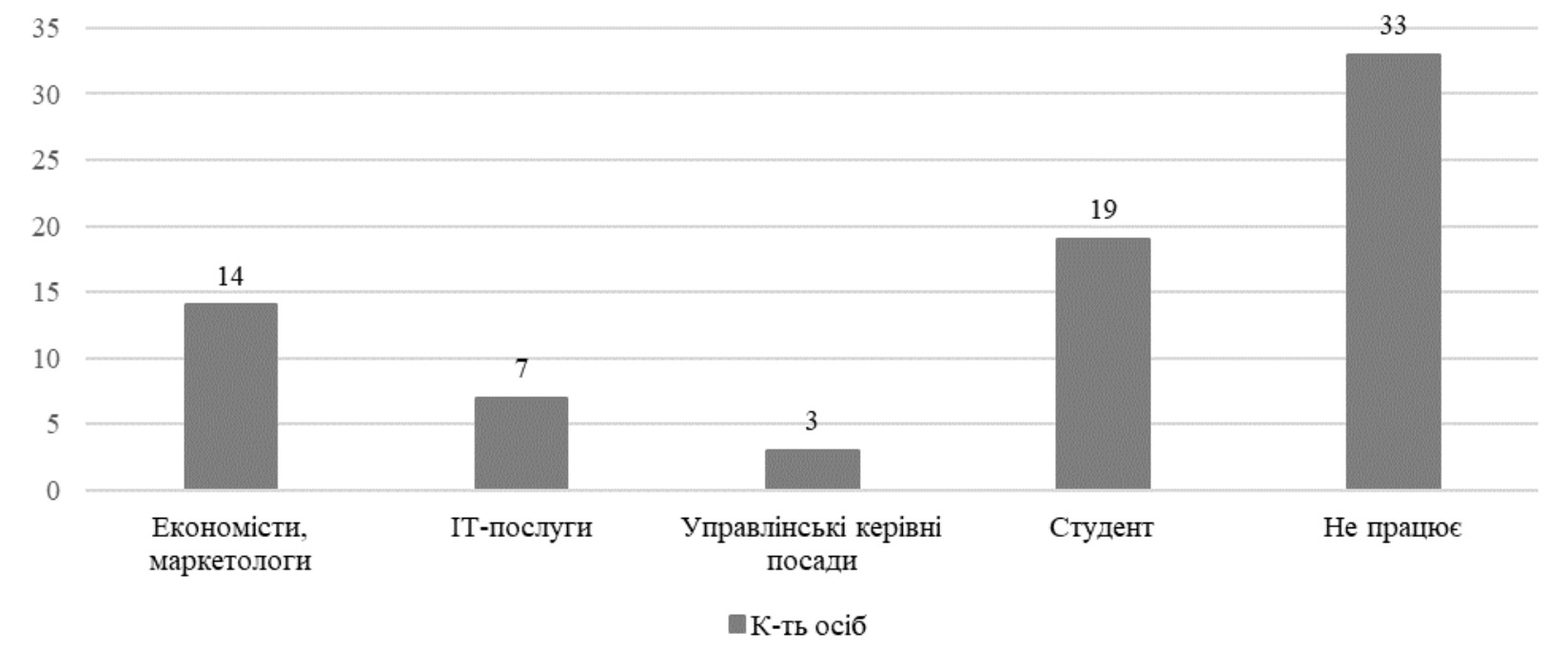

Рис. 1. Співвідношення опитуваних за посадами

Джерело: сформовано авторами

У респондентів був вибір між двома ноутбуками 3 однаковими характеристиками, проте з різною ціною. За результатами дослідження 78.8\% (67 осіб) оберуть товар, ціна на який нижча. Відповідно 21.2\% (18 осіб) опитуваних оберуть більш дорогий ноутбук. Це означає, що для п’ятої частини опитуваних характерний ефект моделі поведінки «ціна - якість». Тобто такі споживачі впевнені, що якісний товар завжди має вищу ціну навіть попри те, що обидва ноутбуки мають однакові характеристики.

Як правило, така модель поведінки характерна для споживачів, чий рівень доходу вище середнього. I в цьому є певна логічна закономірність. У своєму дослідженні А. Маслоу стверджує, що потреби людей поділяються на рівні в ієрархічному порядку. Відповідно для людей з низьким рівнем доходу важливо задовольнити бодай базові потреби людини такі як фізіологічні потреби, та потреба в безпеці. Для тих, хто має вищий рівень достатку, важлива вже не лише наявність благ, але й їх якість та престиж.

Престиж займає не останнє місце в плані поясненні вчинків покупців. Так, за зовнішніми ознаками (одяг, аксесуари) ми розділяємо людей за соціальними рангами. Саме тому більшість прагне до купівлі дорогих авто, розкішного одягу і т.д. Певній групі споживачів важливо те, яке враження вони справляють на інших. 
Престиж та авторитет також $є$ важливими характеристиками і складовими соціального статусу кожного. Символами соціального статусу може бути посада, звання, певні особистісні й ділові якості. Фактично статус $є$ показником визнання значущості особистості з боку групи чи суспільства, у статусі виявляють себе групові норми й цінності [1, С. 147].

Саме цими закономірностями користуються компанії при створенні бренду. Насправді кількість компаній, які справді розуміють, як продавати не товар, а статус, дуже мало. Однією з таких можна вважати компанію Apple. Купуючи продукцію цієї компанії, споживачі платять не за багатофункціональний пристрій, а за статус, який вони отримують разом 3 привласненням продукції. Нижче наведена статистика кількості користувачів продукцією Apple в період 2018-2020 pp. [7].

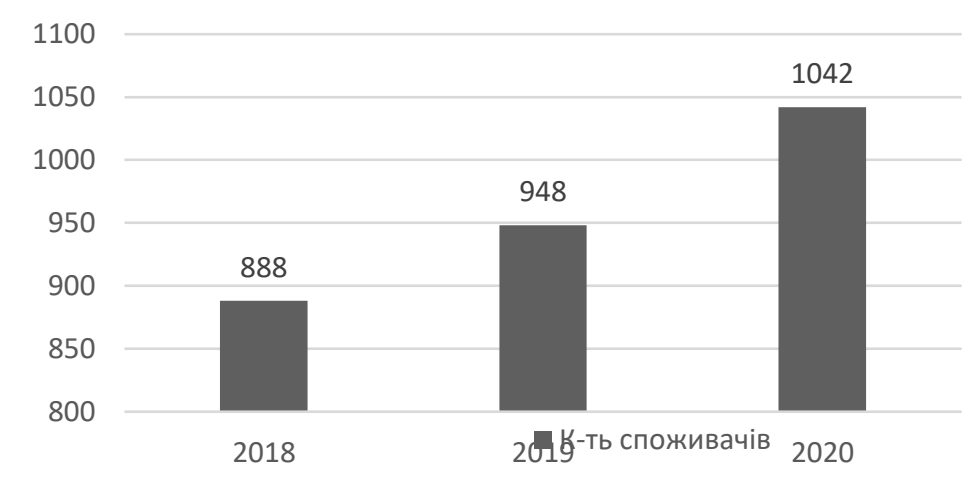

\section{Рис. 2. Кількість користувачів продукцісю Apple}

\section{Джерело: сформовано авторами}

Анкетування також охоплювало питання іміджу та репутації. Так, споживачам було поставлено питання, яку марку телефону вони оберуть, за умови, що вони обіймають високу посаду у відомій фірмі. Отримали наступні результати: 54\% осіб вказали, що оберуть IPhone, 22.5\% віддають перевагу Samsung, всі інші респонденти розділилися за різним відсотковим співвідношенням між іншими марками телефонів, такі як Huawei, Xiaomi, Vivo, ZTI та інші.

Аналізуючи дані, отримані в ході дослідження, ми також отримали, що за умови, якщо у респондентів буде дохід понад 30 тис. грн., 48\% опитуваних придбає новий IPhone за ціною 28 тис. грн.

Коли споживач купує будь-які брендові товари, він задовольняє перш за все свою потребу в приналежності до певної групи населення і лише після цього задовольняє потребу в користуванні товаром. Так, наприклад, респондентам була запропонована ситуація на визначення типу поведінки: у них $є 40$ тис. грн. і їм потрібно придбати ноутбук. При цьому є вибір з трьох моделей: новий ноутбук марки Lenovo Legion 5 за 36 тис. грн; новий ноутбук марки Acer Nitro за 40 тис. грн + колонки в подарунок і б/в MacBook Apple за 25 тис. грн. 
За результатами опитування $27 \%$ споживачів придбають потриманий MacBook замість того, щоб придбати новий ноутбук. Це говорить про те, що цій групі людей притаманний ефект Веблена або як його ще називають ефект демонстративного споживання. Це той випадок, коли споживач купує товар не через потребу в ньому, а через бажання справити враження на оточуючих.

До подібної поведінки схильні люди, які за рахунок придбання нових дорогих товарів намагаються підвищити свій соціальний статус в очах оточуючих. Найчастіше вони схильні до ототожнення таких понять як «вартість» і «корисність», при цьому, не звертаючи належної уваги на якість самого продукту [8].

Проте відповідно до аналізу нами статистичних даних, таких людей серед опитуваних меншість. А от «економічних» споживачів більшість. Дослідження показує, що 40\% (34 особи) опитуваних придбають ноутбук за 36 тис. грн. Про таких споживачів можна сказати, що їхня споживацька поведінка $\epsilon$ раціональною, адже вони зберігають певну частину доходу на випадок непередбачуваних ситуацій.

I власне 33\% (28 осіб) стверджують, що оберуть ноутбук за 40 тис. грн. 3 колонками у подарунок. Відповідно третя частина респондентів $є$ яскравим підтвердженням аксіоми ненасичуваності, коли споживач установлює такий порядок переваг, за якого споживач завжди визнає за краще більшу кількість благ порівняно з меншою. Дані дослідження наведені в табл. 2.

Табличя 2

\section{Відсоткове співвідношення вибору респондентів}

\begin{tabular}{|c|c|c|}
\hline Модель & $\%$ & Кількість респондентів \\
\hline Lenovo Legion 5 & 40 & 34 \\
\hline Acer Nitro & 33 & 28 \\
\hline Mac Apple & 27 & 23 \\
\hline
\end{tabular}

Джерело: сформовано авторами

Ще одним завданням, яке ми хотіли вирішити за допомогою проведення анкетування було дослідити поведінку споживачів на ефект «вірність якості», що демонструє стійку прихильність до певного бренду чи торгівельної марки, яка $є$ своєрідним гарантом якості при купівлі нових товарів. Ми запитали респондентів чи оберуть вони іншу марку телефону, якщо впродовж довгого часу вони купували товари однієї марки, але зараз у них не вистачає на це коштів.

На рис. 3 продемонстровано результати нашого дослідження: 2,5\% (2 особи) за умови нестачі коштів готові взяти кредит, аби придбати товар потрібної їм марки; 35,5\% (30 осіб) придбають товар іншої марки, а 62\% (52 особи) тобто переважна більшість опитуваних, згодні відтермінувати покупку товару з метою накопичення необхідної суми для придбання продукції того бренду, що їм до вподоби. 


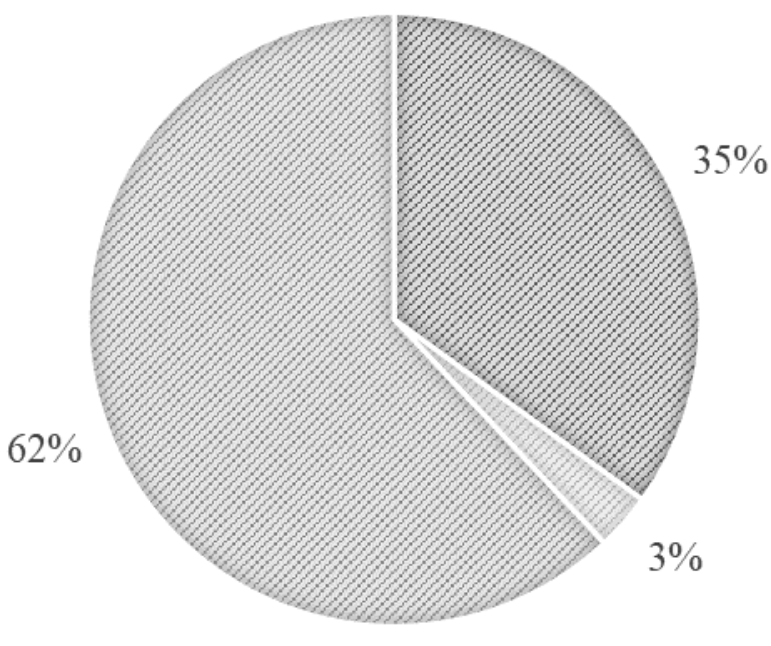

๑беруть іншу марку Візьмуть кредит Кнакопичуватимуть

\section{Рис. 3. Вибір споживачів за ефектом «вірність якості»}

\section{Джерело: сформовано авторами}

Висновки 3 проведеного дослідження. Отже, дослідження моделей поведінки споживачів надали можливість визначити, що для $27 \%$ респондентів характерна модель поведінки споживача з ефектом Веблена, 62\% опитуваних «зберігатимуть вірність» торговій марці за різних умов, в той час як майже 55\% респондентів мають модель поведінки, характерну для ефекту «бендвегона», $48 \%$ опитуваних придбають IPhone за 28 тис. грн. при доході понад 30 тис. грн. i 40\% (що в кількісному вираженні дорівнює 34 людини) проявляють раціональну поведінку. Дослідження за допомогою анкетування допомогли визначити: як покупець приймає рішення про покупку; яким чином зовнішні фактори, а також характеристики покупця впливають на його поведінку.

\section{Перелік посилань.}

1. Ложкін Г. В., Комаровська В. Л., Воленюк Н. Ю. Економічна психологія: навчальний посібник. 3-тє вид., переробл. і доповн. Київ, 2008. $464 \mathrm{c}$.

2. Базилевич В. Д., Базилевич К. С., Ігнатюк А. І., Слухай С. В. Мікроекономіка: підручник / за ред. Базилевича В. Д. Київ, 2008. 679 с.

3. Марті Ньюмеєр Найкращий посібник з брендингу ZAG / перек. 3 анг. "Клуб Сімейного Дозвілля", 2017. 192 с.

4. Зозульов А. В., Кубишина Н.С. Маркетинг: навчальний посібник / під ред. С. А. Солнцева. К.: Знання, 2011. 421 с.

5. Наумік К. Г. Економічна психологія: навчальний посібник. Харків, 2007. $276 \mathrm{c}$.

6. Бондарчук Т. Л. Модель поведінки споживача: теоретикиметодологічні аспекти. Глобальні та наџіональні проблеми економіки. 2016. № 11. С. 3-7. 
7. Офіційний сайт Apple Statistics: веб-сайт. URL: https://www.businessofapps.com/data/apple-statistics/ (дата звернення: 02.09.2021).

8. MGN маркетингове агентство. Показне споживання: стадний ефект або снобізм?: веб-сайт. URL: https://mgn.com.ua/uk/pokaznoe-potreblenie-stadnyjinstinkt-ili-snobizm/ (дата звернення 08.09.2021).

9. Роберт Пиндайк, Даниэль Рабинфельд Мікроекономіка; 5-те вид., перек. 3 анг. Київ, 2011. 608 с.

10. Башнянин Г. І., Зав'ялова О. Р. Мікроекономічна теорія: навчальний посібник. 3-тє вид. Львів, 2020. 391 с.

\section{References}

1. Lozhkin, H. V., Komarovska, V. L., Voleniuk, N. Yu. (2008). Economic psychology [Ekonomichna psykholohiia]: textbook, 3rd ed., Kyiv, 464 p.

2. Bazylevych, V. D., Bazylevych, K. S., Ihnatiuk, A. I., Slukhai, S. V. (2008). Microeconomics [Mikroekonomika]: textbook, Kyiv, 679 p.

3. Newmeyer, M. (2007). The best guide to ZAG branding [Naikrashchyi posibnyk z brendynhu ZAG]: trans. from Eng."Klub Simeinoho Dozvillia", 192 p.

4. Zozulov, A.V. (2011). Marketing [Marketynh]: textbook/ pid red. S. A. Solntseva. K.: Znannia, $421 \mathrm{p}$.

5. Naumik, K. H. (2007). Economic psychology [Ekonomichna psykholohiia]: textbook. Kharkiv, $276 \mathrm{p}$.

6. Bondarchuk, T. L. (2016). Model of consumer behavior: theoristsmethodological aspects [Model povedinky spozhyvacha: teoretyky-metodolohichni aspekty]. Global and national economic problems, No. 11, P. 3-7.

7. Official site of Apple Statistics: website, available at: https://www.businessofapps.com/data/apple-statistics/ (last accessed 02.09.2021).

8. MGN marketing agency. Showy consumption: herd effect or snobbery? [Pokazne spozhyvannya: stadnyy efekt abo snobizm?]: web site, available at: https://mgn.com.ua/en/pokaznoe-potreblenie-stadnyj-instinkt-ili-snobizm/ (last accessed 08.09.2021).

9. Pyndaik, R., Rabynfeld, D. (2011). Microeconomics [Mikroekonomika] / 5th ed., trans. from Eng. Kyiv, 608 p.

10. Bashnianyn, H. I., Zavialova, O. R. (2020). Microeconomic theory [Mikroekonomichna teoriia]: textbook, 3rd ed. Lviv, $391 \mathrm{p}$. 


\section{РЕФЕРАТИ РЕФЕРАТЫ ABSTRACTS}

\section{УДК: 339.138; JEL Classification: M31 \\ Жалдак Г.П., Яценко А. М. АНАЛІЗ ФАКТОРІВ ТА МОДЕЛЕЙ ПОВЕДІНКИ СПОЖИВАЧА}

Мета дослідження: окреслити основні фактори та моделі поведінки споживача у сучасних умовах. Методика дослідження. Для вирішення мети, нами було: проведено аналітичне дослідження стосовно змін споживача про купівлю товарів в залежності від зміни зовнішніх та внутрішніх факторів; визначено особливості поведінки покупців враховуючи споживчі переваги продукту та структуру споживання. Результати дослідження. У статті висвітлюються як зовнішні, так і внутрішні фактори, що впливають на поведінку споживачів, описуються моделі поведінки споживачів. Проаналізовано, як компанії використовують результати дослідження поведінки споживачів у своїй діяльності. Висвітлюються основні фактори, що впливають на рішення покупця придбати товар. У статті досліджено, як споживач змінює своє рішення про купівлю товару залежно від зміни зовнішніх та внутрішніх факторів, визначили особливості поведінки споживача 3 урахуванням споживчих уподобань товару та структури споживання. В дослідженні представлено результати анкетування 85 осіб щодо їхнього вибору товарів побутової техніки. Наведені результати дослідження щодо того, як соціум впливає на прийняття рішення індивідом. Наукова новизна: Визначено як компанії можуть використовувати психологічні та соціально-економічні аспекти поведінки споживача у побудові процесу виробництва та розробці маркетингової стратегії. Практичне значення отриманих результатів. Виходячи 3 цього можна зробити висновок, що спираючись на результати дослідження поведінки споживачів, компанія зможе значно покращити процес виробництва. Практична цінність дослідження полягає в тому, що підприємство на основі результатів анкетування може відносно передбачити поведінку покупця в певних ситуаціях і відповідно до цього розробити вдалу рекламну кампанію та регулювати обсяги виробництва того чи іншого товару, що може суттєво вплинути на дохід підприємства.

Ключові слова: споживач; ринок вільної конкуренції; вибір споживача; поведінка споживача.

УДК: 339.138; JEL Classification: M31

Жалдак А.П., Яџенко А.Н. АНАЛИЗ ФАКТОРОВ И МОДЕЛЕЙ ПОВЕДЕНИЯ ПОТРЕБИТЕЛЯ

Цель исследования: определить основные факторы и модели поведения потребителя в современных условиях. Методика исследования. Для решения цели, нами было: проведено аналитическое исследование по изменению решения потребителя о покупке товаров в зависимости от изменения внешних и внутренних факторов; определены особенности поведения покупателей учитывая потребительские преимущества продукта и структуру потребления. Результаты исследования: В статье высветлены как внешние, так и 
внутренние факторы, влияющие на поведение потребителей, описываются модели поведения потребителей. Проанализировано, как компании используют результаты исследования поведения потребителей в своей деятельности. Обозначены основные факторы, влияющие на решение покупателя приобрести товар. В статье мы исследовали, как потребитель меняет свое решение о покупке товара в зависимости от изменения внешних и внутренних факторов, определили особенности поведения потребителя с учетом потребительских предпочтений товара и структуры потребления. В статье представлены результаты анкетирования 85 человек по их выбору товаров бытовой техники. Приведенные результаты исследования того, как социум влияет на принятие решения индивидом. Научная новизна: Определено как компании могут использовать психологические и социально-экономические аспекты поведения потребителя в построении процесса производства и разработке маркетинговой стратегии. Практическое значение полученных результатов: Исходя из этого можно сделать вывод, что, опираясь на результаты исследования поведения потребителей, компания сможет значительно улучшить процесс производства. Практическая ценность исследования заключается в том, что предприятие на основе результатов анкетирования может относительно предсказать поведение покупателя в определенных ситуациях и в соответствии с этим разработать удачную рекламную кампанию и регулировать объемы производства того или иного товара, может существенно повлиять на доход предприятия.

Ключевые слова: потребитель; рынок свободной конкуренции; выбор потребителя; поведение потребителя

\section{UDK: 339.138; JEL Classification: M31}

\section{Zhaldak H.P., Yatsenko A.M. ANALYSIS OF FACTORS AND MODELS OF CONSUMER BEHAVIOR}

Purpose: an analytical study on changes in the consumer's purchase of goods depending on changes in external and internal factors; the peculiarities of customer behavior are determined taking into account the consumer preferences of the product and the structure of consumption. Research methodology. To solve the goal, we conducted: In the article we investigated how the consumer changes his decision to buy goods depending on changes in external and internal factors, identified the characteristics of consumer behavior taking into account consumer preferences and consumption structure. Results: The article highlights both external and internal factors influencing consumer behavior, describes models of consumer behavior. It is analyzed how companies use the results of consumer behavior research in their activities. The main factors influencing the buyer's decision to buy the product are highlighted. The purpose of the article is to outline the main factors and models of consumer behavior in modern conditions. The article presents the results of a survey of 85 people on their choice of household appliances. Originality: The results of a study on how society influences individual decision-making are presented. It is defined how companies can use psychological and socio-economic aspects of consumer behavior in building the production process and developing a marketing strategy. Practical value: Based on this, we can conclude that based on the results of 
research on consumer behavior, the company will be able to significantly improve the production process. The practical value of the study is that the company based on the results of the survey can relatively predict the behavior of the buyer in certain situations and accordingly develop a successful advertising campaign and regulate the production of a product that can significantly affect the company's income.

Keywords: consumer; free competition market; consumer choice; consumer behavior.

\section{Відомості про авторів / Сведения об авторах / About the Authors}

Жалдак Ганна Петрівна - кандидат економічних наук, доцент, Національний технічний університет України «Київський політехнічний інститут імені Ігоря Сікорського», м. Київ, Україна, e-mail: Ann17@i.ua; ORCID: https://orcid.org/0000-0003-3421-3648. Моб. 096-735-23-90.

Жалдак Анна Петровна - кандидат экономических наук, доцент, Национальный технический университет Украины «Киевский политехнический институт имени Игоря Сикорского», г. Киев, Украина.

Zhaldak Hanna Petrovna - Candidate of Economic Sciences, Associate Professor, National Technical University of Ukraine "Kyiv Polytechnic Institute named after Igor Sikorsky", Kyiv, Ukraine.

Яценко Анна Миколаївна - студентка, Національний технічний університет України «Київський політехнічний інститут імені Ігоря Сікорського», м. Київ, Україна, e-mail: anikastorm938@gmail.com; ORCID: https://orcid.org/0000-0003-3630-4930. Моб. 099-731-77-89.

Яценко Анна Николаевна - студентка, Национальный технический университет Украины «Киевский политехнический институт имени Игоря Сикорского», г. Киев, Украина.

Yatsenko Anna Mykolayivna - student, National Technical University of Ukraine "Kyiv Polytechnic Institute named after Igor Sikorsky", Kyiv, Ukraine. 